\title{
Using Extensive Reading to Develop Non-major Students' Reading Skill at Hochiminh City University of Food Industry in Vietnam
}

\author{
Nguyen Thi Kim Anh 8 (D) \\ Faculty of Foreign Languages, Hochiminh city University of Food Industry, Vietnam \\ $\triangle$ Corresponding Author: Nguyen Thi Kim Anh, E-mail: anhntkim@huffi.edu.vn
}

\author{
ARTICLE INFORMATION \\ Received: May 14, 2021 \\ Accepted: June 12, 2021 \\ Volume: 3 \\ Issue: 6 \\ DOI: $10.32996 /$ jeltal.2021.3.6.6
}

\section{KEYWORDS}

Innovating English Teaching Methods, Extensive reading, Reading motivation, Reading ability

\section{ABSTRACT}

The purpose of this paper was to investigate the benefits extensive reading can bring to non-major students and lectures at Hochiminh City University of Food Industry (HUFI). The study addressed a main research question and two sub-research questions related to extensive reading: How does extensive reading develop students' reading comprehension and improve vocabulary at Hochiminh City University of Food Industry? Two sub-research questions: To what extent could extensive reading help to enhance students' reading skill? The participants of this study were non-major students at HUFI in Vietnam. The research instruments used in this study to collect data were three main instruments, namely Reading Tests (including Pre-Reading Test and Post-Reading Test), Questionnaire, and Interview. The result of data analysis revealed a significant difference. The findings suggested that innovating lectures' teaching methods by extensive reading could help students improve their reading ability, particularly their reading comprehension and vocabulary, by engaging them in a systematic extensive reading program.

\section{Introduction}

Nowadays, English is considered the official or second or foreign language in many countries. Thus it is a crucial subject in schools and universities. The graduates need to acquire good English competence and performance to meet their profession's requirements. English is a foreign language taught to non-major students at the Hochiminh city University of Food Industry (HUFI). In order to manipulate English effectively and successfully throughout their career, they have to develop all language skills, especially reading skill which is an essential skill in the academic environment.

In the curriculum of Hochiminh city University of Food Industry (HUFI) (2020), English is the main subject taught in total 180 periods (a period is 45 minutes long). All students have to gain level B1 - following the Vietnamese Standardized Test of English Proficiency (VSTEP) before graduation. Moreover, they have to enrich their knowledge with the help of a great deal of English document for their future job, which requires their autonomy. Actually, non-major students face so many problems and difficulties while reading English books, for which there are some reasons: their poor vocabulary and lack of motivation to read. Besides, the method of teaching reading is old-fashioned, mainly based on translation. It does not motivate students to read the things chosen for students by teachers. In many cases, students are not interested in the topics.

My ambition is to find an effective teaching method that can increase students' reading ability and improve their vocabulary. During the searching process, I find it necessary to deploy the extensive reading program which a number of researchers (Mason \& Krashen, 1997; Mori, 2002; Hitosugi \& Day, 2004; Pigada \& Schmitt, 2006; Takase, 2007; Nishino, 2007) consider the most effective way works in ESL and EFL learners' improvement of vocabulary and reading competence. This study consists of three purposes. First, I would like to examine the effects of extensive reading in developing students' reading ability in my university. Second, I find out how extensive reading motivates students in reading. Lastly, I want to discover the students' opinions toward extensive reading.

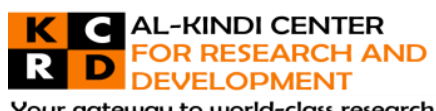

Your gateway to world-class research

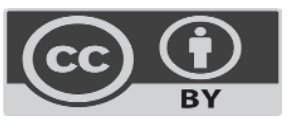

Published by Al-Kindi Center for Research and Development, United Kingdom. Copyright (c) the author(s). This open access article is distributed under a Creative Commons Attribution (CC-BY) 4.0 license 
Consequently, the research questions are: (1)Can extensive reading develop students' reading ability and motivation at HUFI? (2) Does extensive reading enhance students' reading motivation? And (3) Do students recognize the benefits that extensive reading bring them?

\section{Literature Review}

In 1998 Day and Bamford defined extensive reading as an approach to teaching and learning language requiring learners to read more books than required following a syllabus and the books must be appropriate to learners' linguistic competence. Richards and Schmidt (2002) claimed that to gain a general understanding of what is read, extensive reading is considered the reading activities in quantity. Similarly, in 1999 Jacobs, Rcnandy \& Rajan considered extensive reading the activity of reading a large number of books and materials independently to enrich knowledge and entertain. Furthermore, Day and Bamford (2002) suggested top ten principles for teaching extensive reading". They include easy material, available range of reading materials on a variety of topic, assurance of students' choice of materials, maximum reading, pleasure of reading, reading in its own reward, individual and silent reading, reading under teachers' orientation and guidance teachers' role model.

If foreign language students read sufficient materials, they can improve their vocabularies, read more fluently, upgrade their writing ability (Mason \& Krashen, 1997). Bell (1998) also confirmed that extensive reading is a factor consolidating learners' language competence and stimulating exposure to language; enlarging vocabulary; creating confidence, and enriching prediction skills". There are many benefits of extensive reading. Day and Bamford (1998), Nation (1997) mentioned automaticity of word recognition, large vocabulary, acquisition of grammar, quick and accurate process of sentence structures. As a result, learners take an active attitude toward reading.

A large number of researchers has recognized the benefits of extensive reading. They also discuss the relationship between motivation and extensive reading because motivation plays an important role in mastering successful reading strategies. Day and Bamford (1998) defined motivation as the things that make people do (or not do) something. Later, Day and Bamford provided four major factors in the expectancy model of second language reading motivation. They include reading materials, reading ability, attitudes toward reading, and the socio-cultural environment. Exciting reading materials, the first priority, must be at an appropriate level for learners. Reading ability is mentioned because it is necessary for the learners with low reading skill not to be worried. Therefore, they should have the right to choose suitable books at their level. The materials they choose to read must be easy to comprehend, ranging from low to high. The free choice of reading material brings students positive attitudes toward reading in the second language. The time is flexible, so they do not have to finish their reading at an allocated time. The place they read can be inside or outside class. Lastly, the extensive reading program forms a socio-cultural environment that can increase the learners' reading abilities. Among the above factors, materials and attitudes are the key ones in forming motivation in reading. Attitudes and motivation can be developed positively by using extensive reading.

There are some arguments about reading motivation between first language and second or foreign language. In first language reading, motivation was categorized into eleven sub-components by Wigfield and Guthrie (1995) among which five are in the competence and social aspects of reading as "reading efficacy, challenge, work avoidance, compliance, and social reasons. The others are extrinsic and intrinsic motivation. In 2003, Takase, who applied an extensive reading program to investigate motivations in foreign language reading among Japanese university students, claimed that participants' motivation changed greatly with the assistance of extensive reading.

\section{Methodology}

\section{1 Methods}

This research used quantitative and qualitative methods. During the extensive reading, experimental students faced different difficulties from other countries because of ethnic features. Social and cultural background may be obstacles in reading comprehension that I do not want to affect the research results. Secondly, I need a profound insight into the motivation the extensive reading brings to the EFL students. This is also the purpose of qualitative methodology claimed by Hinchey (2008). Furthermore, qualitative methodology shows the exact numbers on their progress in their reading skill (Maria Smith, Tamsin Bowers-Brown, 2010). In order to collect data for my research, I had the experimental students do a pre-test and a post-test, then complete a questionnaire and answer the interview questions. 


\subsection{Participants}

I randomly chose a class 11DHTH8 of non-major 42 students from the classes in which I taught English as a foreign language at the Hochiminh city University of Food Industry (HUFI), my workplace. The site of my research is located in Tan Phu district, Ho Chi Minh City, Vietnam.

\subsection{Research Procedures}

I conducted the research with the participation of 42 students who volunteer. I divided these participants into two groups (experimental group and control group). This study lasted 8 weeks.

At the first stage of the experiment, all the students in both groups were required to do the Pre-reading Test. At the second stage of the experiment

In the experimental group:

a. The objectives of this study and the procedure of the eight-week extensive reading program were introduced to the students.

b. The teacher provided the students with a wide range of books available in the library of HUFI to raise their interest.

c. The students choose some books in the library, the length of which depends on their ability. They were given 4 days to finish each book. The number of books supposed to be read was at least 10 books during the program.

d. The place where the students read the books is flexible depending on their choice at home or at school. They could spend their break at school or free time at home.

e. The students filled in the book report form after finishing each book. The students were encouraged not to use a dictionary while reading the books, which improved their ability to predict the meanings of new words.

f. In every class, the students could express their feelings about the books and their problems during the reading process.

At the final stage of the experiment, the Post-reading Test was given to forty-two participants and they had to complete the detailed Reading Motivation Questionnaire. Finally, 9 random students in the experimental class were interviewed by the researcher.

\subsection{Data Analysis}

Paired t-test of SPSS 16.0 for WINDOW to determine the Mean scores (M) and Standard Deviation (SD) in Pre-reading test was employed in both classes (experimental class and control class)by the researcher which were then compared to identify the statistically significant difference.

The information from the Reading Motivation Questionaire was analyzed by using descriptive statistics to find out the answers for the sub-research questions. SPSS 16.0 for WINDOW was exploited to determine the Mean (M) and Standard Deviation (SD) in each class from analyzed information of the Questionnaire which showed the difference between the mean score from the self-ratings of RMQ. 30 items were included in the RMQ on the motivation's four factors related to reading: Extrinsic Utility Value of Reading, Importance of Reading, Intrinsic Value of Reading, and Reading Efficacy. The results revealed the motivation change of the experimental students before and after the extensive reading program.

The researcher aimed at investigating exactly the learners' opinions about ER and identifying the students' attitudes toward the ER through the individual interview. Nine participants ( 6 male and 3 female students) making up $43 \%$ out of 21 students in the experimental class, were interviewed at the end of ER program. Each interview lasted about 10 minutes. The use of digital media for recording met with the interviewees' approval. The researcher recorded and watched videotapes of interviews and transcribed them verbatim immediately, which helped the research focus on every detail of the interviews. After multiple reading, transcripts were described, coded and compared in order to withdraw conclusions. The classified and coded data showed students' attitudes towards extending reading, their enrichment of vocabulary, difficulties and hobbies, and their wishes.

\section{Results and Discussion}

The aim of this research was to examine whether the extensive reading program could develop students' reading ability and enhance students' reading motivation. Also, the purpose of the study was to find out the change in students' attitudes toward the extensive reading program after following the teacher's instructions. In this part, I will demonstrate the experiment results drawn from quantitative and qualitative methods of data analysis. In the first section, the results are based on data analysis of students' scores of the pre-reading test and post-reading test, and the discussions about the results are revealed. In the next section, the process of conducting a survey by using the self-ratings of the Reading Motivation Questionnaire and the logical 
inferences discussion are shown. And in the last section, the analysis of the codes and the themes from the individual interview and the students' attitudes toward Extensive Reading are displayed.

\subsection{Results and Discussions from Pre- and Post-reading Test}

Pre-reading Test and Post-reading Test are used to discover whether the extensive reading program can improve students' reading skill and inspire them to read. The differences between the results from the tests can lead to the discussion on the effectiveness of the application of the new method, which will be presented in this section. Particularly, qualitative analysis of variance brings us deep insight into the students'progress due to the extensive reading program.

\subsubsection{Analysis of Scores of Pre-Reading Test before ER with SPSS statistics}

Table 2 Difference Mean Scores of Pre-Reading Test before ER

\begin{tabular}{|c|c|c|c|c|c|c|c|c|}
\hline \multirow{4}{*}{ Pair 2} & & \multicolumn{5}{|c|}{ Paired Differences } & \multirow{3}{*}{$\mathrm{t}$} & \multirow{3}{*}{ Sig. (2-tailed) } \\
\hline & \multirow{3}{*}{$\begin{array}{c}\text { pretest_experiment_ } \\
\text { class-pretest_ } \\
\text { control_class }\end{array}$} & \multirow[t]{2}{*}{ Mean } & \multirow[t]{2}{*}{ Std. Deviation } & \multirow[t]{2}{*}{ Std. Error Mean } & \multicolumn{2}{|c|}{$\begin{array}{c}\text { 95\% Confidence Interval of } \\
\text { the } \\
\text { Difference }\end{array}$} & & \\
\hline & & & & & Lower & Upper & & \\
\hline & & 0.17 & 0.411 & 0.089 & -.008 & .366 & 1.987 & .061 \\
\hline
\end{tabular}

There is a similarity between the experimental class's mean scores and the control class's ones. It proves that the students in both classes are at the same competence before the extensive program.

\subsubsection{Analysis of Scores of Students' Post-test Reading with SPSS statistics}

Analysis of Scores of Students' Post-test Reading with SPSS statistics showed that the mean scores of the experimental class were 7.29 with SD of 0.578 and the ones of control class were 6.14 with SD of 0.752 , which reveal the mean scores of experimental were higher than control class's ones

Table 3 Mean Scores of Post-reading Test after ER

\begin{tabular}{|c|c|c|c|c|c|}
\hline \multirow{3}{*}{ Pair 3 } & & Mean & N & Std. Deviation & Std. Error Mean \\
\cline { 2 - 7 } & Post-test_experiment_class & 7.29 & 21 & .578 & .126 \\
\cline { 2 - 7 } & Post-test_control_class & 6.14 & 21 & .752 & .164 \\
\hline
\end{tabular}

Table 4 displayed the comparison of scores of both classes, control and experimental classes. The difference was confirmed by the mean scores (1.15) with the SD of $0.502(t=10.521)$

Table 4 Paired Difference Mean Scores of Post-reading Test after ER

\begin{tabular}{|c|c|c|c|c|c|c|c|c|}
\hline \multirow{4}{*}{ Pair 4} & \multirow{4}{*}{$\begin{array}{c}\text { Post-test_experiment_class } \\
\text { Post-test_control_class }\end{array}$} & \multicolumn{5}{|c|}{ Paired Differences } & \multirow{3}{*}{$\mathrm{t}$} & \multirow{3}{*}{$\begin{array}{l}\text { Sig. (2- } \\
\text { tailed) }\end{array}$} \\
\hline & & \multirow[t]{2}{*}{ Mean } & \multirow[t]{2}{*}{ Std. Deviation } & \multirow[t]{2}{*}{$\begin{array}{l}\text { Std. Error } \\
\text { Mean }\end{array}$} & \multicolumn{2}{|c|}{$\begin{array}{c}95 \% \text { Confidence } \\
\text { Interval } \\
\text { of the Difference }\end{array}$} & & \\
\hline & & & & & Lower & Upper & & \\
\hline & & 1.15 & .502 & .109 & .925 & 1.383 & 10.521 & .000 \\
\hline
\end{tabular}

Tables 3 and 4 revealed the progress the experimental class made after extensive reading.

\subsubsection{Differences between the Mean Scores of Students' Pre- and Post-reading Test in Experimental Class}

The results in table 5 showed that the mean scores of post-test ( 7.29 with SD of 578) done by the students in the experimental class were higher than those of pre-test (6.19 with SD of 680) done by themselves, which demonstrated the progress they made after the extensive reading program.

Table 5 Mean Score of the Reading Pretest and Posttest after ER in Experimental Class

\begin{tabular}{|c|c|c|c|c|c|}
\hline \multirow{3}{*}{ Pair 5 } & & Mean & N & Std. Deviation & Std. Error Mean \\
\cline { 2 - 7 } & Post_test_experimental_class & 7.29 & 21 & .578 & .12633 \\
\cline { 2 - 7 } & Pre-test_experimental_class & 6.19 & 21 & .680 & .148 \\
\hline
\end{tabular}

Table 6 showed the differences between the means of the reading test before and after the ER. 
Table 6 Means of the Reading Test before and after ER in Experimental Class

\begin{tabular}{|c|c|c|c|c|c|c|c|c|}
\hline \multirow{4}{*}{ Pair 6} & & \multicolumn{5}{|c|}{ Paired Differences } & \multirow{3}{*}{$\mathrm{t}$} & \multirow{3}{*}{$\begin{array}{l}\text { Sig. (2- } \\
\text { tailed) }\end{array}$} \\
\hline & \multirow{3}{*}{$\begin{array}{c}\text { posttest_experimental_class } \\
\text { vs. pretest_ } \\
\text { experimental_class }\end{array}$} & \multirow[t]{2}{*}{ Mean } & \multirow[t]{2}{*}{$\begin{array}{c}\text { Std. } \\
\text { Deviation }\end{array}$} & \multirow[t]{2}{*}{$\begin{array}{c}\text { Std. Error } \\
\text { Mean }\end{array}$} & \multicolumn{2}{|c|}{$\begin{array}{l}95 \% \text { Confidence } \\
\text { Interval } \\
\text { of the Difference }\end{array}$} & & \\
\hline & & & & & Lower & Upper & & \\
\hline & & 1.10 & .464 & .101 & .895 & 1.318 & 10.91 & .004 \\
\hline
\end{tabular}

Table 6 showed the significant difference between the means of the reading test before and after extensive in experimental class, which certified development of students' reading comprehension and vocabulary enrichment and the effects of extensive reading on students' reading ability.

\subsubsection{Differences between the Mean Scores of Students' Pre- and Post-reading Test in Experimental Class}

The further analysis of the mean score of the reading pretest and posttest after the ER showed that the students in the experimental class outperformed in their reading test. Table 5 showed the mean score of the posttest before ER was 7.29 with SD of 578 but the mean scores of pre-test after ER was 6.19 with SD of 680. It was higher than the mean scores of the pretest.

Table 5 Mean Score of the Reading Pretest and Posttest after ER in Experimental Class

\begin{tabular}{|c|c|c|c|c|c|}
\hline \multirow{4}{*}{ Pair 5 } & & Mean & N & Std. Deviation & Std. Error Mean \\
\cline { 2 - 6 } & Post_test_experimental_class & 7.29 & 21 & .578 & .12633 \\
\cline { 2 - 7 } & Pre-test_experimental_class & 6.19 & 21 & .680 & .148 \\
\hline
\end{tabular}

Table 6 showed the differences between the means of the reading test before and after the ER.

Table 6 Means of the Reading Test before and after ER in Experimental Class

\begin{tabular}{|c|c|c|c|c|c|c|c|c|}
\hline \multirow{4}{*}{ Pair 6} & & \multicolumn{5}{|c|}{ Paired Differences } & \multirow{3}{*}{$\mathrm{t}$} & \multirow{3}{*}{$\begin{array}{l}\text { Sig. (2- } \\
\text { tailed) }\end{array}$} \\
\hline & \multirow{3}{*}{$\begin{array}{c}\text { posttest_experimental_class } \\
\text { vs. pretest_ } \\
\text { experimental_class }\end{array}$} & \multirow[t]{2}{*}{ Mean } & \multirow[t]{2}{*}{$\begin{array}{c}\text { Std. } \\
\text { Deviation }\end{array}$} & \multirow[t]{2}{*}{$\begin{array}{c}\text { Std. Error } \\
\text { Mean }\end{array}$} & \multicolumn{2}{|c|}{$\begin{array}{l}\text { 95\% Confidence } \\
\text { Interval } \\
\text { of the Difference }\end{array}$} & & \\
\hline & & & & & Lower & Upper & & \\
\hline & & 1.10 & .464 & .101 & .895 & 1.318 & 10.91 & .004 \\
\hline
\end{tabular}

The overall mean score was shown rather higher than the former. Particularly, the paired t-tests' results denoted the students' development of their reading comprehension and vocabulary knowledge which was also a substantial improvement of their reading ability.

Based on the results with SPSS statistics above, we can realise both the students' improvement of reading comprehension and their vocabulary enrichment in the experimental class. It can lead to the conclusion that the extensive reading program can develop students' reading ability.

\subsection{Results and Discussions from the Students' Reading Motivation toward the ER}

The data collected from the questionaire aimed at finding out the answer to part of the research question:"How does the extensive reading develop non-major students at HUFI, my workplace.

The analysis of the students' scores of the pre-and post-reading motivation questionnaire was examined. The results show the differences between the mean scores of students' pre-and post-reading motivation in four variables: Intrinsic Value, Extrinsic Utility Value, the Importance of Reading and Reading Efficacy are presented.

The analysis of the self-ratings from the pre-and post-reading Motivation Questionnaire in accordance with the four variables also showed that the students had made a significant change in each variable of the reading motivation after the ER as presented in Table 7.

As illustrated in Table 7, the overall means of the Reading Motivation Questionnaire (RMQ) self-ratings were classified into 4 categories. First, in terms of Intrinsic Value of Reading, the overall means of the self-ratings from the pre-and post-Reading Motivation Questionnaires were 2.56 and 4.23, respectively. Second, regarding the Extrinsic Utility Value of Reading, the overall means of the self-ratings from the pre-and post- Reading Motivation Questionnaires were 2.73 and 4.09, respectively. A significant difference was found between the means of the pre-and the post questionnaires with SD of 0.89 and 0.70 ( $t=$ 16.87). Third, with regard to the Importance of Reading, the overall means of the self-ratings from the pre-and post-Reading 
Motivation Questionnaires were 2.88 and 4.42, respectively. A significant difference was found between the means of the preand the post questionnaires SD of 0.86 and $0.72(t=19.29)$. Last, in term of the Reading Efficacy, the overall means of the selfratings from the pre- and post-Reading Motivation Questionnaire were 2.16 and 4.33, respectively. A significant difference was found between the means of the pre-and the post questionnaire SD of

0.86 and $0.71(t=20.04)$. The results indicated that after participating in the ERP the latter mean scores of students' reading motivation in all 4 categories were higher than the former.

Table 7 Self-ratings from the Pre- and Post-reading Motivation Questionnaire

\begin{tabular}{|c|c|c|c|c|c|c|c|}
\hline \multirow{2}{*}{$\begin{array}{c}\text { Categories of Reading } \\
\text { Motivation }\end{array}$} & $\mathrm{N}$ & \multicolumn{2}{|c|}{ Before ER } & \multicolumn{2}{|c|}{ After ER } & \multirow{2}{*}{$\mathrm{t}$} \\
\cline { 3 - 8 } & & Mean & Std. Deviation & Mean & Std. Deviation & \\
\hline Intrinsic Value of Reading & 21 & 2.56 & .87 & 4.23 & .67 & 14.23 & 0.00 \\
\hline Extrinsic Utility Value of Reading & 21 & 2.73 & .89 & 4.09 & .70 & 16.87 & 0.00 \\
\hline Importance of Reading & 21 & 2.88 & .86 & 4.42 & .72 & 19.29 & 0.00 \\
\hline Reading Efficacy & 21 & 2.16 & .86 & 4.33 & .71 & 20.04 & 0.00 \\
\hline Overall & 21 & $\mathbf{2 . 5 8}$ & .87 & $\mathbf{4 . 2 7}$ & .71 & $\mathbf{1 7 . 6 1}$ & 0.00 \\
\hline
\end{tabular}

The analysis of these results revealed that four categories of reading motivation had affected students' reading motivation. The evidence mentioned previously can be concluded that the extensive reading program helps students increase their reading motivation and students' reading.

\subsection{Results and Discussions from Interview}

The results from the interview questions related to students' attitudes toward extensive reading (ER) show that most of the students had a positive attitude toward ER by giving similar opinions with valued positive reading experiences: The students had gains in vocabulary and comprehension texts, their confidences were increased in reading English, they were also happy to be able to read much and longer English texts, and their spare time was used effectively when they took part in ER.

The interview consists of the first question as "Do you often spend much time reading English books and materials before taking part in the research? What are the reasons?". All the students said that they did not read English books because they thought they could not read them with their poor vocabulary.

"How much time a day do you spend on extensive reading?" was the next interview question. Five out of nine answers were more than 2 hours; the others were over 1.5 hours. The average time is approximately two hours which was used for ER.

The third interview question was on the number of books they read during the experiment. Two out of nine interviewees read 12 books, three out of nine students read 9 books and four out of nine students read 8 books. So average books they had read are more than 9 books.

The fourth interview question was about the full extent of reading the books chosen. All nine students (100\%) answered they did not finish all the books. The reasons given were lack of time to read, too thick books.

The $5^{\text {th }}$ interview question was, "Do you prefer extending reading? What are the reasons?" $100 \%$ of the answers were "YES". They like ER because they could select their own books. These books helped them improve their vocabulary as they are exposed to more words.

The sixth question was "Do you find extensive reading useful for you?" The answer was the same as the $4^{\text {th }}$ and $5^{\text {th }}$ questions' ones. $100 \%$ students answered "yes". Then they were asked an open-ended question: "Why do you think extensive reading is useful for you?" Student L: "Extensive reading helped me know a lot of vocabulary. I was very happy if I know the meanings of unknown words. I could remember the words after I looked up in the dictionary". Student K: "After reading the books, I know more words. It has improved my vocabulary." They were satisfied with their richer vocabulary. Another usefulness is their interest and self-confidence in reading English was increased. Student N: "I like reading English more". Student P said that he had chosen 12 books 9 of which he could finish, though. However, he was inspired to read by extensive reading. He could select books and read on his own. Student B: "The last term I didn't like to read, I rarely read an English book, but now I'm very happy and fell more confident in reading English"

All of students answered 'yes' to the last interview question, "Are you going to use extensive reading in the future?" and they hoped extensive reading developed in their English courses.

These findings above may show that when students feel improved in their reading ability, they tend to have a positive attitude 
toward what they have experienced. It is like this "improved reading ability

$\Leftrightarrow$ positive attitude". That means their reading proficiency was improved a great deal, it held a positive attitude toward the reading English.

\section{Conclusion}

As an English teacher, I realized that non-major students at my school, HUFI, found it hard to do reading comprehension tasks. They still had a low degree of reading skill which is essential in their job future. They will have to read many documents in English. Therefore, I searched for more effective methods to assist them in improving their reading skill and motivating them to read as much as possible. In the end, I made up my mind to employ extensive reading to aim at the goals. The process of research reveals several findings. Firstly, extensive reading upgrades the students' reading skill and enriches their vocabulary. Secondly, extensive reading stimulates young people to read more books, raises their desire to discover new things. Finally, extensive reading builds up a positive attitude towards reading tasks. Nevertheless, applying this method to teaching reading skills at universities encountered some difficulties, such as limited time and a range of books. However, I do not think they are great difficulties that we overcome easily.

The findings in quantitative data showed that using ER in innovative English teaching methods has helped students develop their reading ability. Surprisingly, they can read and understand the whole story though they do not know the meaning of every word. The extensive reading program helps students to improve their reading comprehension and to gain more words. So, it can be concluded that the extensive reading program can improve students' reading ability.

The findings from the Reading Motivation Question and interviews showed that the reading motivation had been significantly increased. The students' motivation revealed that lecturers use the ER, which helps students increase their reading motivation. During the 8 weeks extensive reading program students enjoyed reading and felt comfortable reading. As a result, it can be concluded that the students have been satisfied with the extensive reading program.

\section{References}

[1] Bell T. (1998). Extensive reading: Why? And How? , The Internet TESL Journal, Vol. 4.

[2] Day R. and Bamford J. (1998). Extensive Reading in the Second Language Classroom. Cambridge: Cambridge University Press. Day R. and Bamford J. (2002). Top ten princeples for teaching extensive reading", Reading in a Foreign Lanuage, 4(2)

[3] El ley W. B. and Mangubhai F. (1981) The Impact of a Hook Flood in Fiji Primary Schools, Wellington: New Zealand Council for Educational Research.

[4] Hitosugi C. I. and Day R. R. (2004). "Extensive reading in Japanese", Reading in a Foreign Language, 16(1)

[5] Jacobs G. M., Rcnandy W. A. and Rajan B. (1999). "Extensive reading with adult learners of English as a second language", RELC Journal , 30, $39-61$.

[6] Krashen S. D. (1982). Principle and Practices in Second Language Acquisition, New York: Prentice Hall.

[7] Mason B. and Krashen S. (1997). "Extensive reading in English as a foreign language", System, 25(1), 91-102.

[8] Mori S. (2002). Redefining motivation to read in a foreign language", Reading in a Foreign Language, Vol. 14.

[9] Mori S. (2004). Significant motivational predictors of the amount of reading by EFL learners in Japan", RELC Journal, 35(1), 63-81.

[10] Nation P. (1997). The language learning benefits of extensive reading", The Language Teacher, 21(5), 13-16.

[11] Nishino T. (2007). Beginning to read extensively: A case study with Mako and Fumi", Reading in a Foreign Language, 19(2), 76-105.

[12] Pigada M. and Schmitt N. (2006). Vocabulary acquisition from extensive reading: A case study", Reading in a Foreign Language, 18(1)

[13] Richards J. C. and Schmidt R. (2002). Longman Dictionary of Language Teaching and Applied Linguistics (3rd ed.), London: Longman.

[14] Takase A. (2007). Japanese high school students' motivation for extensive L2 reading, Reading in a Foreign Language, 19(1).

[15] Takase A. (2003). The effects of extensive reading on the motivation of Japanese high school", [Unpublished doctoral dissertation], Temple University, Japan.

[16] Wigfield A. and Guthrie J. T. (1995). Dimensions of children's motivations for reading: An initial study (Research Rep. No. 34)", Athens, GA: National Reading Research Center.

[17] Wigfield A. and Guthrie J. T. (1997). Relations of children's motivations for reading to the amount and breadth of their reading, Journal of Educational Psychology, 89, 420-432. 